РОЗДІЛ 5. РІВЕНЬ РОЗВИТКУ ТЕХНОЛОГІЙ ЗАХИСТУ НАВКОЛИШНЬОГО СЕРЕДОВИЩА

DOI https://doi.org/10.36059/978-966-397-247-3-11

Ігнатишин В. В.

кандидат фізико-математичних наук, старший науковий співробітник Відділу сейсмічності

Карпатського регіону

Інститут геофізики імені С. І. Субботіна

Національної академії наук України

м. Львів, Україна;

доцент кафедри географії та туризму

Закарпатський угорський інститут імені Ференца Ракоці II

м. Берегове, Закарпатська область, Україна

\title{
СПОСТЕРЕЖЕННЯ ГЕОФІЗИЧНИХ ПОЛІВ, ДОСЛІДЖЕННЯ ЇХ ЗВ'ЯЗКУ ІЗ СУЧАСНИМИ ГОРИЗОНТАЛЬНИМИ РУХАМИ КОРИ ТА ПРОЯВОМ СЕЙСМІЧНОСТІ ЗАКАРПАТСЬКОГО ВНУТРІШНЬОГО ПРОГИНУ В 2020 РОЦІ
}

Проведено спостереження параметрів радіоактивного фону середовища в Закарпатському внутрішньому прогині, досліджено зв'язок геофізичних полів із параметрами геодинамічного та сейсмічного станів в регіоні, що характеризується підвищеною сейсмічною активністю з метою покращення екологічного стану Закарпаття. Використано результати спостережень на режимних геофізичних станціях, сейсмічних станціях та пунктах деформометричних спостережень Відділу сейсмічності Карпатського регіону Інституту геофізики ім. С.І. Субботіна НАН України Параметри радіоактивного фону( бета випромінювання) спостережувані на РГС „Тросник” корелювали із сучасними горизонтальними рухами кори в зоні Оашського глибинного розлому: стиснення порід супроводжувалися підвищеним радіоактивним фоном. Сейсмічність регіону супроводжує інтенсивні рухи кори, згідно часового розподілу швидкостей сучасних горизонтальних рухів кори. Актуальність проведених 
Сучасна траєкторія розвитку науково-технічного прогресу в Україні та світі

досліджень викликана періодичністю сейсмотектонічних процесів та зменшення частоти прояву відчутних місцевих землетрусів. Для даного регіону частота прояву відчутних місцевих землетрусів становить від 2-х до 6 підземних поштовхів. Тому важливо продовження вивчення зв'язку геофізичних полів із сейсмотектонічними процесами та вирішення проблем екологічного стану регіону.

\section{Вступ}

Важливість вивчення геомеханічних процесів в сейсмоегенеруючих регіонах очевидна оскільки процес дослідження геофізичних процесів необхідний для створення реальної картини геологічних явищ в досліджуваному регіоні. Геодинамічний стан визначає динаміку геологічних процесів в регіоні зокрема сейсмічних явищ. На основі реальної моделі сучасних рухів кори-вертикальних та горизонтальних можна охарактеризувати напружено-деформований стан порід, його стадії в процесі підготовки та прояву місцевої сейсмічності. Для вивчення геодинаміки регіону використовуються різні методи: нахиломірні спостереження, деформометричні спостереження, геодезичні вимірювання, методи дистанційного зондування Землі та інш. Важливе місце в дослідженні геологічних явищ в сейсмонебезпечних регіонах яким $є$ Закарпатський внутрішній прогин $\epsilon$ вивчення факторів, що безпосередньо впливають на процес формування екологічно-небезпечного явища: метеорологічних, гідрогеологічних, агрофізичних та астрофізичних. Необхідно відмітити важливість проведення вимірювання параметрів геофізичних полів, оскільки саме вони першими реагують на геомеханічні зміни навколишнього середовища, а саме на земну кору верхні шари мантії, де можлива генерація енергії, що вивільнятиметься через підземні поштовхи. Саме в рядах спостережуваних параметрів доступних до вивчення геофізичних та інших полів, слід досліджувати ефекти та особливості, що передують прояву підземних стихій. На сьогоднішній період коло доступних до вивчення геофізичних полів невелике, проте і ці поля важливо досконально дослідити на предмет зв'язку а можливо і взаємозв'язку із варіаціями параметрів геодинамічного стану середовища, що $\epsilon$ відображенням геологічних процесів в середовищі. В даному дослідженні використано елементи радіоактивного фону 
Сучасна траєкторія розвитку науково-технічного прогресу в Україні та світі

середовища, зокрема бета-випромінювання. Вивченню зв'язку інших геофізичних полів із сейсмотектонікою регіону (Закарпатського внутрішнього прогину) приділено достатню увагу, тут отримано вагомі результати, зокрема, вивчення магнітного поля Землі, що на даний період $\epsilon$ одним із найдоступнішим методом дослідження. Представлені результати дослідження радіоактивного фону середовища в контексті вивчення їх зв'язку із рухами кори та зареєстрованими місцевими землетрусами $\epsilon$ новими. Закарпаття та його геологічні структури $\epsilon$ територією, де реєструються місцеві землетруси різної енергії (магнітуди, бальності), на їхньому фоні періодично сейсмічні станції в Закарпатті та прилеглих територіях сусідніх країн, відмічають землетруси більшої магнітуди, відповідно і бальності за шкалою MSK-64. Найголовніша причина подальшого вивчення всіх геофізичних явищ та супроводжуючих їх полів - це безпека людини. Саме це актуалізує інші причини досконального вивчення геодинамічних процесів в екологічно-небезпечних регіонах. Метою дослідження є вивчення стану геодинаміки регіону, просторово-часового розподілу місцевої сейсмічності, просторово-часового розподілу параметрів геофізичних полів у мовах підвищеної екологічної небезпеки геологічного характеру. Об"єктом дослідження є сейсмотектонічні процеси в регіоні в 2020 році. Предметом дослідження $€$ зв'язки між сучасними горизонтальними рухами кори та сейсмічністю регіону, варіаціями радіоактивного фону середовища та просторовочасовим розподілом сейсмічності в Закарпатському внутрішньому прогині за 2020 рік. Методи дослідження: проведено побудову просторово-часового розподілу місцевої сейсмічності за 2020 рік, представлено зміщення порід в зоні Оашського глибинного розлому, використано динамічні параметри сучасних горизонтальних рухів кори, представлено часовий розподіл бета випромінювання та досліджено їхні взаємозв'язки. Для вирішення поставлених геофізичних задач використано результати геофізичного, геодинамічного та сейсмічного моніторингу Закарпатського внутрішнього прогину, проведених на режимних геофізичних станціях, пунктах деформометричних спостережень Відділу сейсмічності Карпатського регіону та Карпатського відділення Інституту геофізики ім. С.I. Субботіна НАН України за 2020 рік. 
Сучасна траєкторія розвитку науково-технічного прогресу в Україні та світі

\section{1. Аналіз результатів наукових досліджень геодинамічного та геофізичного станів в регіоні}

Дослідженню процесів у верхніх шарах земної кори за результатами геофізичних моніторингів присвячено багато наукових публікацій вчених різних природничих напрямків. Особливо увага приділена регіонам, які небезпечні в плані екологічної безпеки, зокрема Закарпатського внутрішнього прогину та інших сейсмоегенеруючих територій. Вивчаються як геологічні так і геофізичні особливості таких територій. Аналізуються зв'язки геофізичних полів та геологічних процесів в регіоні. Зокрема чималу увагу приділено вивченню магнітного поля Землі та його фізичних характеристик.

Геомагнітне поле широко застосовується для отримання інформації щодо глибинної будови та розвитку літосфери Землі, дрібномасштабного прогнозування корисних копалин, а також вирішення низки екологічних завдань [1]. Досліджено, що існують критичні величини деформації, при досягненні яких в одноріднодеформованих пружних ізотропних середовищах не можуть поширюватися пружні поздовжні й поперечні хвилі з речовинною швидкістю. Кількісні значення критичних величин деформацій для поздовжніх і поперечних хвиль відрізняються та істотно залежать від застосованих пружних потенціалів [2]. Представлено методику визначення деформаційних характеристик шарів розрахункових моделей грунтової товщі для еквівалентного лінійного і нелінійного моделювання іï реакції на сейсмічні впливи [3]. Проведено вивчення механізму вогнищ місцевих землетрусів в Закарпатському внутрішньому прогині та відмічена особливість вивчених вогнищ, яка полягає в тому, що в межах тієї самої території відбуваються землетруси протилежних типів що досить логічно з урахуванням того, що в тиловій зоні насувів формуються умови розтягу в тому самому напрямку, що й стиснення в їхній фронтовій частині [4]. Розглянуто методики визначення магнітного поля літосфери, проблеми його виділення та інтерпретації, проаналізовано методи моделювання регіональних магнітних тіл, оскільки останні роки накопичився великий об'єм векторних і скалярних магнітних даних, які стали доступними до обробки [5]. Для визначення головних осей тензора напружень за результатами тектонофізичних досліджень в Закарпатті у [6] застосовано кінематичний метод для опрацювання тектонічних дзеркал 3 бороздами ковзання та 
структурно-парагенетичний метод для обробки розривів без слідів переміщення. У зв'язку з ростом кількості природнотехногених катастроф розроблено систему моніторингу за станом геологічного середовища 3 використанням сучасного математичного апарату та інформаційних технологій, зокрема локальний моніторинг територій розташування потенційно небезпечних об'єктів- радіоізотопні дослідження густини та вологості грунтів по периметру збудованих споруд [7]. У [8] проведено т порівняння сейсмічних зображень, що отримані 3 використанням графічних процесорів та програмного забезпечення власної розробки, при цьому використано реальні сейсмограми спільних джерел, отримані на площі із складною геологічною будовою та мають некоректну просторову дискретизацією. Виконано аналіз вікових змін магнітного поля Землі та їі сейсмічності для періоду 1950-2000 рр. Для аналізу використано головне магнітне поле Землі, що дозволяє вивчати характерні особливості магнітних аномалій з розмірами в перші тисячі кілометрів. Вперше встановлено зв'язок між ділянками 3 підвищеною сейсмічною активністю та областями додатного приросту "мантійно-літосферної" компоненти геомагнітного поля, які в тектонічному відношенні відповідають зонам зчленування літосферних плит [9]. Розглянуто особливості утворення та поширення низькочастотних сейсмічних сигналів літосферного походження, проаналізовано діапазони поширення мікросейсмічних хвиль у земній корі, визначено умови поширення мікросейсмічних сигналів у земній корі, їх розповсюдження від неоднорідностей геологічного середовища, встановлено характер взаємодії мікросейсм з геологічною будовою на денній поверхні та форму іï відображення, проаналізовано характеристики мікросейсмічних хвиль та визначено найбільш інформативний діапазон для геологічного дослідження [10]. Запропоновано концептуальну модель формування Латорицько-Стрийської зсувної зони та Східних Карпат: горизонтальне витискання флішових мас до північного заходу вздовж простягання орогену із сильно стисненої області у менш стиснену область, що розташована перед терейном Алькапа, відмічено різний ступінь стиску флішових утворень перед терейнами зумовлений різною швидкістю руху терейнів у бік флішового поясу[11]. Запропоновано метод, заснований на вивченні закономірностей зміни та розвитку властивостей порід, що $\epsilon$ важливим під час 
прогнозування, оскільки саме він дає інформацію про явища, які передують зміщенню порід; застосування методу ПІЕМПЗ використовується для здійснення якісного вирішення актуальних питань [12]. Підготовлено електронну тектонічну карту України $з$ векторами горизонтальних складових швидкостей GNSS станцій; відмічено: значення визначених швидкостей $є$ однорідними і 3 збільшенням часового інтервалу спостережень створюється можливість встановити особливості просторового розподілу руху земної кори на території України [13]. Оцінювання та аналіз деформаційних полів Землі - одне 3 пріоритетних завдань сучасної геодинаміки, яке вирішується комплексно зусиллями різних природничих наук; розроблена на цій основі методика деформаційного аналізу має вищий інформативний ресурс, забезпечує адекватні GNSS-даним оцінки деформаційних полів і перспективу передачі нелінійних деформацій [14]. Виконано низку трансформацій осереднення гравіметричних i магнітометричних матеріалів та побудовано карти локальних аномалій поля сили тяжіння і магнітного поля. У результаті аналізу морфології спостережених гравімагнітних полів та локальних аномалій виявлено характерні ознаки відображення крупних тектонічних зон, регіональної поведінки поверхні фундаменту, простежено глибинні розломи та палеодолини, виявлено протяжні зони зміни характеру потенціальних полів та побудовано оглядові схеми розломної тектоніки Західного регіону України[15]. Розглянуто міграцію твердої оболонки планети по рідкофазній покрівлі зовнішнього ядра - нижня астеносфера - під впливом ротаційно-гравітаційного механізму. Ротаційно-гравітаційний режим Землі, представляється основним механізмом структурної перебудови тектоносфери, який привів до формування на максимумах різновікових i різноспрямованих антіформ екваторіальних ротаційних рифтогенних здуттів планети[16]. Вивчення матеріалу, 3 урахуванням нової геолого-геофізичної інформації, свідчить про те, що в межах Західної і Центральної Європи відсутні ознаки, що дають підставу трактувати ділянку земної кори (між Карпатами та Східно-Європейською платформою) як "молоду платформу" [17]. Відмічено: радонові аномалії генеруються радіоактивними елементами ураном і торієм, які концентруються в породах, грунтах і підземних водах, особливо в зонах впливу розломів, активних у сучасну епоху; максимальна кількість радону 
встановлена в геодинамічних активних зонах покривних відкладів, які пов'язані з розривними порушеннями в корінних породах[18]. Обернення хвильових форм лише прямих Р-хвиль, дає змогу визначати механізм вогнища землетрусу за даними малої кількості станцій, що особливо актуально у регіонах 3 порівняно невисоким рівнем місцевої сейсмічної активності [19]. Встановлено, що поверхнева геологія, яка суттєво впливає на поширення сейсмічних хвиль є одним з головних факторів, який визначає сейсмічний ефект на поверхні грунту, реакція якого залежить від літологічного складу, фізичних параметрів, потужності, водонасиченості грунтових шарів, інтенсивності землетрусу, частотного складу коливань у його джерелі і на покрівлі консолідованого фундаменту під майданчиком [20]. Досліджено зв'язок геофізичних полів із геодинамічним станом в Закарпатському внутрішньому прогині [21]. Розглянуто зв'язок гідрогеологічного та сейсмотектонічного станів в Закарпатському внутрішньому прогині, відмічено гідрогеологічнй аспект сейсмотектонічних процесів [22]. Дослідження геофізичних процесів в Закарпатському внутрішньому прогині за 2019 рік відмітили особливості геодинамічного стану регіону [23]. Дослідження геодинамічних процесів в Закарпатському внутрішньому прогині за 2019 рік вказали на розширення порід та на їх періодичність [24]. Представлено методичні аспекти застосування результатів геофізичних спостережень при вивченні геодинамічного стану Закарпатського внутрішнього прогину при викладанні „Фізики 3 основами геофізики при підготовці географів [25]. Показано результати вивчення зв'язку деформацій земної кори із сейсмічністю Закарпатського внутрішнього прогину за 2017 рік землетруси відбуваються в інтервалах зміни знаку зміщень земної кори в зоні Оашського розлому [26]. Застосування параметрів кінематики сучасних горизонтальних рухів земної кори при вивченні сейсмічного стану Закарпатського внутрішнього прогину за 2017 рік відмітили залежність розрядки напружено-деформованого стану порід від величини швидкості та прискорення сучасних горизонтальних рухів кори [27]. Знаки сучасних горизонтальних рухів в зоні Оашського глибинного розлому та сейсмічна активність Закарпатського внутрішнього прогину зв'язані - стиснення порід супроводжується проявом місцевої сейсмічності [28]. Розглянуто особливості просторово- 
часового розподілу сейсмічності Закарпатського внутрішнього прогину та геодинамічний стан регіону та вказано на їх періодичність, на залежність часу розрядки геомеханічної енергії від впливу супутника Землі, Сонця [29].

\section{2. Моніторинг геофізичних полів в Карпатському} геодинамічному полігоні за 2020 рік

На території Закарпаття спостереження проводяться на пунктах геофізичних, сейсмологічних та деформометричних спостережень Відділу сейсмічності Карпатського регіону та Карпатського відділення Інституту геофізики ім. С.І. Субботіна НАН України (рисунок 1).

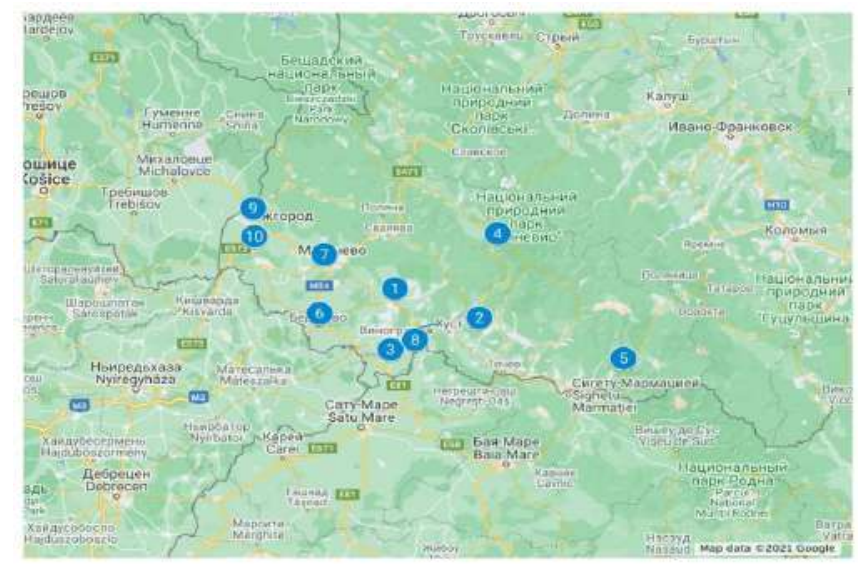

Рис. 1. Сейсмологічні та деформометричні спостереження на Закарпатті. (1 - РГС«Брід»; 2 - РГС «Нижнє Селище»; 3 - РГС «Тросник»; 4 - Сейсмічна станція «Міжгіря»; 5 - сейсмічна станція «Рахів»; 6 - РГС «Берегове»; 7 - РГС«Мукачево»; 8 - пункт деформометричних спостережень «Королеве»; 9 - Сейсмічна станція «Ужгород»;

10 - сейсмічна станція«Холмці» Карпатської дослідно-методичної геофізичної та сейсмологічної партії Відділу сейсмічності

Карпатського регіону Інституту геофізики ім. C.I. Субботіна НАН України [30] 
Сучасна траєкторія розвитку науково-технічного прогресу в Україні та світі

Розраховано сучасні рухи кори - зміщення кори, виміряне на пункті деформометричних спостережень „Королеве” за 2020 рік. Вимірювані дані рухів кори в режимі одної години. Результати вимірювані за допомогою деформометра з азимутом 80 градусів, напрямком схід-захід в штольні пункту деформографічних спостережень „Королеве”. Проведені вимірювання рухів кори в 2019 році вказали на розширення порід кори величиною $+6.5 \times 10^{-7}$. Отримані результати моніторингу деформації земної кори відмітили подальше розширення кори, що спостерігається від 1999 року-початку деформометричних спостережень в регіоні. По-перше вивчено рухи кори в план їх характеру та періодичностей в місячних добових діапазонах. Враховано підсилення деформометра, що становить 0.138 мкм на 1 мм фото запису деформограми. Сучасні горизонтальні рухи кори в зоні Оашського глибинного розлому $\epsilon$ періодичними. Загальна тенденція рухів кори є розширення порід 3 величиною:+10×10-7. Величина зміщення земної кори виміряна на ПДС „Королеве” становить стиснення порід величиною - 28 нстр. Сейсмічність регіону представлена 182 місцевими землетрусами в тому числі одного відчутного, зареєстрованого 23 січня 2020 року на території Берегівського району Закарпатської області. Вперше за період з липня 2015 року на території Закарпаття зареєстровано відчутний місцевий землетрус величиною 4-5 бали за шкалою MSK-64. Більша частина місцевих сейсмічних подій реєструється під час стиснення порід, виміряних на ПДС „Королеве”.

Проведено аналіз результатів спостереження в-випромінювання на РГС „Тросник” за період 2020 року. Вимірювання проводяться за допомогою дозиметра, на території режимної геофізичної станції „Тросник” Карпатської досліднометодичної геофізичної та сейсмологічної партії Відділу сейсмічності Карпатського регіону Інституту геофізики ім. C.I. Субботіна НАН України. Спостереження проводяться за допомогою дозиметра 4 рази на добу, вимірюючи бета -, та гамавипромінювання. Проведено побудову часового розподілу місцевої сейсмічності, радіоактивного фону, та рухів кори, зокрема її динамічних характеристик в місячному діапазоні та проведено аналіз графіків на предмет вивчення їх зв'язків помісячно (рисунок 2). 


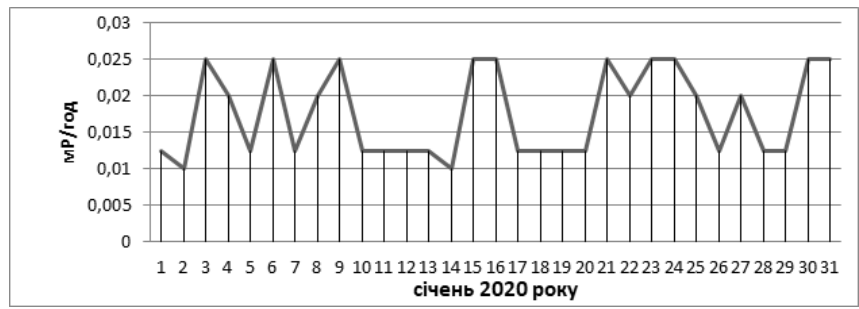

Рис. 2. Варіації радіоактивного фону середовища на РГС «Тросник» в січні 2020 року

Середньомісячна величина спостережуваного випромінювання за січень 2020 року становить 17 мкР/год, на кривій залежності виділено 4 періоди, характерні підвищеними величинами радіоактивного фону. Розглянуто зв'язок варіацій бета-випромінювання на центральній частині Закарпатського внутрішнього прогину та просторово-часовий розподіл місцевої сейсмічності (рисунок 3.)

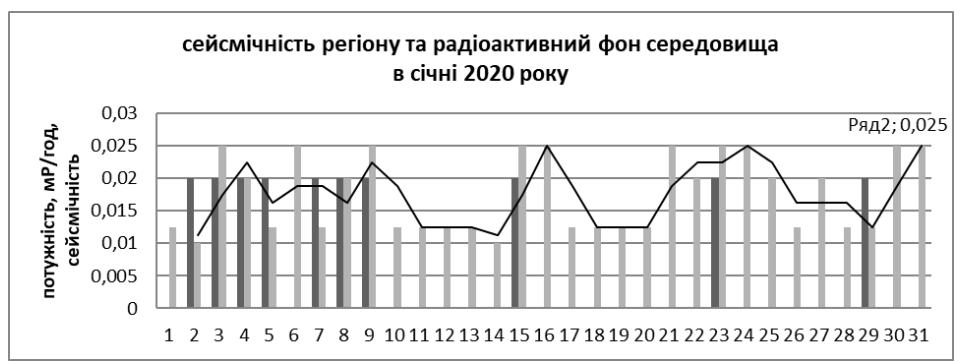

Рис. 3. Сейсмічність Закарпатського внутрішнього прогину (діаграма чорного кольору) та бета-випромінювання на РГС «Тросник» (діаграма сірого кольору) в січні 2020 року

Спостерігаються радіоактивного фону сейсмічності регіону, які знаходять в однакових часових інтервалах. Землетруси передують та супроводжують аномальні періоди радіоактивного фону бета-випромінювання. Наклавши на графіки просторово-часового розподілу місцевої сейсмічності та варіацій радіоактивного фону середовища в регіону за спостережуваний період картину геодинамічного стану 
Сучасна траєкторія розвитку науково-технічного прогресу в Україні та світі

середовища, представлену сучасними горизонтальними рухами земної кори в зоні Оашського глибинного розлому, отримаємо модель геофізичного та сейсмічного стану середовища за січень 2020 року (рисунок 4). Слід відмітити, що 23 січня 2020 року був зареєстрований відчутний місцевий землетрус інтенсивністю 4 бали за шкалою MSK-64, який $є$ першим після тривалого періоду затишшя. Останні відчутні місцеві землетруси на території Закарпаття були зареєстровані в липні -серпні 2015 року, на фоні десятків слабких підземних поштовхів.

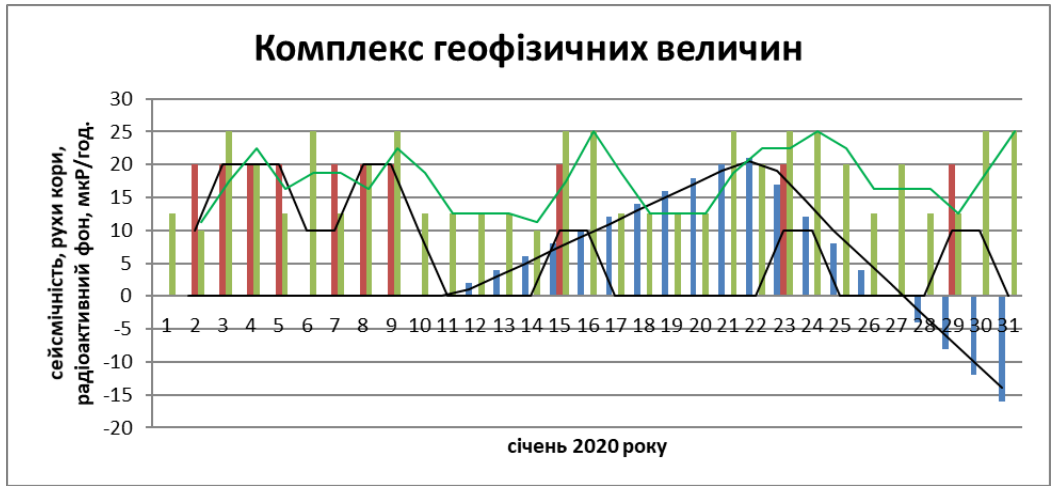

Рис. 4. Сейсмічність регіону (діаграма червоного кольору); сучасні горизонтальні рухи кори (діаграма синього кольору); радіоактивний фон (бета-випромінювання (діаграма зеленого кольору). Січень 2020 року. Закарпатський внутрішній прогин

Геодинаміка регіону за січень 2020 року представлена загальним стисненням порід, динамічною зміною знаку деформацій в другій половині місяця. Знакозмінний процес в рухах кори в другій половині місяця відбувся після сейсмічної активізації регіону, що супроводжувався підвищенням величини бета-випромінювання. Сейсмічність регіону супроводжувала інтервали часу, коли відмічали розширення та стиснення порід, сейсмічність активізувалася також в часових інтервалах інтенсивного переходу системи від розширення до стиснення порід. В лютому 2020 року проведене вимірювання бетавипромінювання на режимній геофізичні станції „Тросник “показали: середньомісячне значення потужності іонізаційного випромінювання становить 0.015 мР/год( рисунок 5). 


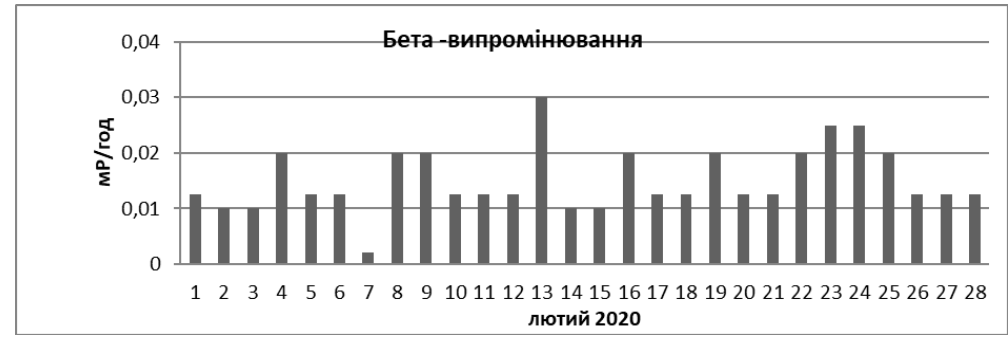

Рис. 5. Бета випромінювання на РГС «Тросник» в лютому 2020 року

Періодичні варіації бета-випромінювання в лютому порівняли із сучасними горизонтальними рухами кори в зоні Оашського глибинного розлому (рисунок 6).

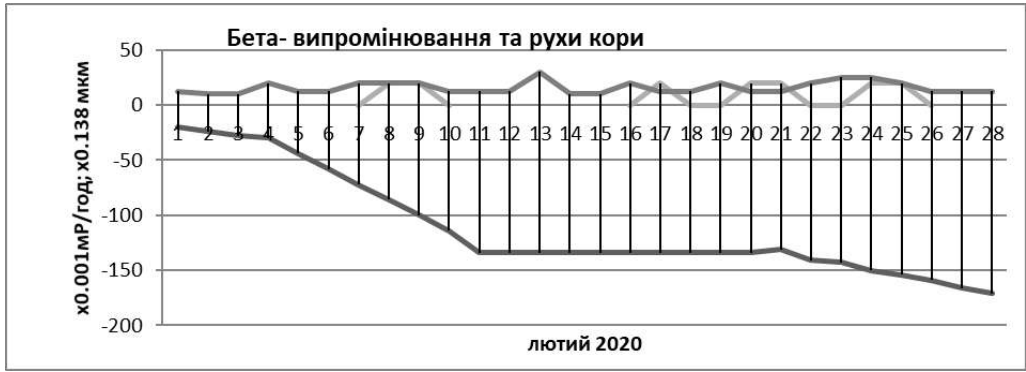

Рис. 6. Сучасні рухи кори в зоні Оашського глибинного розлому (крива чорного кольору) та бета випромінювання (крива сірого кольору) в лютому 2020 року

Варіації радіоактивності в лютому 2020 року представлені на фоні стиснення порід в зоні Оашського глибинного розлому. Підвищення бета-випромінювання супроводжується інтенсивними рухами кори. Попередні дослідження показали на активізацію місцевої сейсмічності в періоди стиснення верхніх шарів земної кори, зокрема, в центральній частині Закарпатського внутрішнього прогину, тому актуально побудувати просторово-часовий розподіл місцевої сейсмічності в лютому 2020 року (рисунок 7). 
Сучасна траєкторія розвитку науково-технічного прогресу в Україні та світі

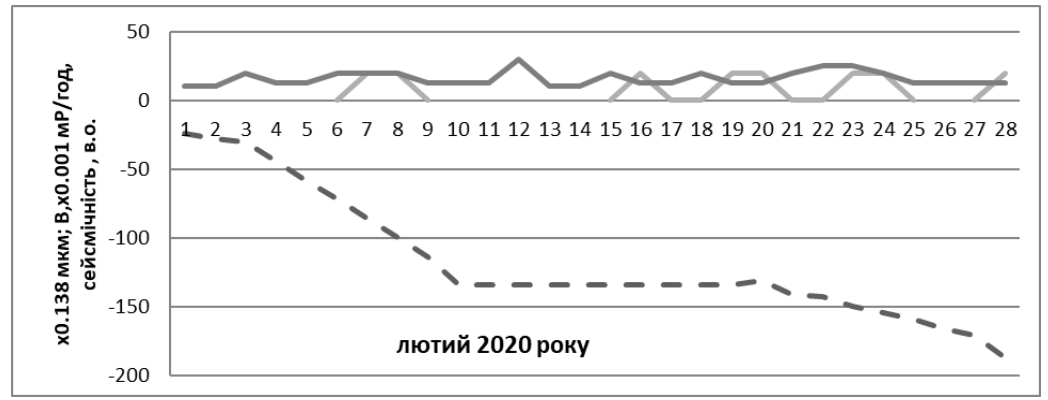

Рис. 7. Комплекс геофізичних спостережень в лютому 2020 року: сейсмічність (крива сірого кольору); бета-випромінювання (крива чорного кольору; рухи кори( штрих - лінія).

Аналіз комплексу геофізичних спостережень в лютому 2020 року показав: сейсмічність регіону відмічена в періоди стиснення земної кори та в другій половині місяця. Таким чином, сейсмічність в Закарпатському внутрішньому прогині реєструється в інтервалах підвищення радіоактивного фону як перед землетрусами так і після них, що може привести до припущення, що землетруси також джерело зміни радіоактивного фону. Фізичний зміст зв'язку радіоактивності середовища та прояву місцевої сейсмічності: інтенсивні рухи кори, та швидкі зміщення порід через струси викликають вивільнення елементів продуктів радіоактивного розпаду, що знаходяться в гірських породах, перенесених туди різними способами. В березні 2020 року зареєстровано середньомісячну величину бета випромінювання на РГС „Тросник” : 0.013 мР/год (рисунок 8).

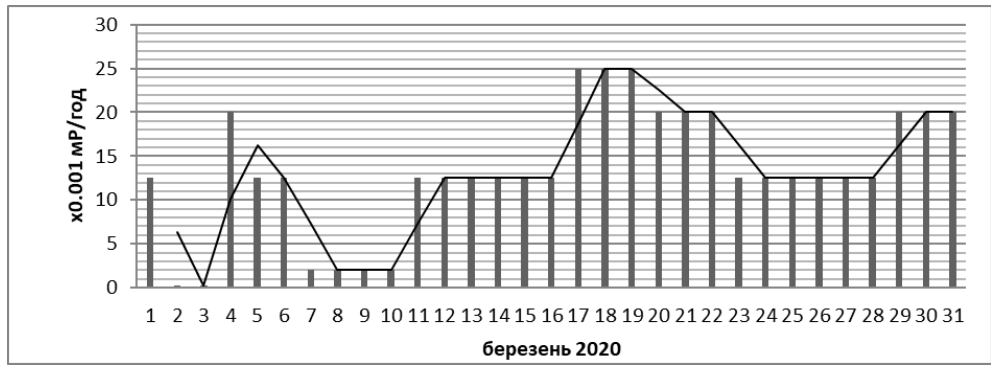

Рис. 8. Бета-випромінювання на РГС «Тросник» за березень 2020 року 
Сучасна траєкторія розвитку науково-технічного прогресу в Україні та світі

Інтенсивність бета-випромінювання зростає прямо пропорційно часові. Розглянуто сейсмічність регіону та радіоактивний фон за березень 2020 року (рисунок 9).

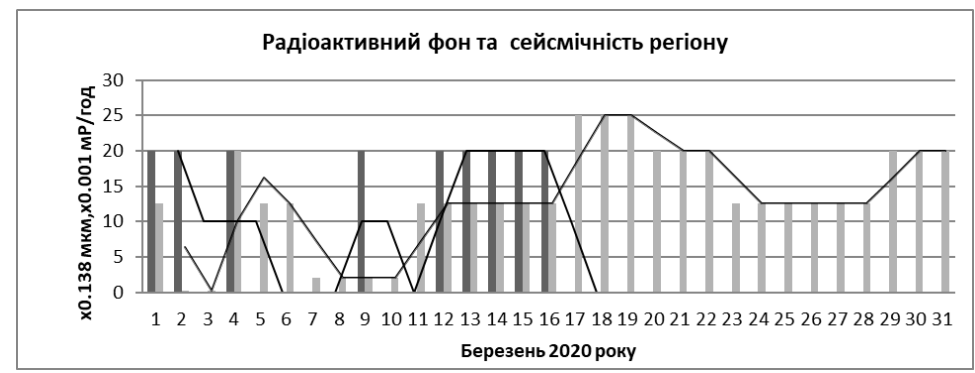

Рис. 9. Радіоактивний фон (бета - випромінювання)-діаграма сірого кольору; сейсмічність регіону (діаграма чорного кольору). Березень 2020 року

Сейсмічність зареєстровано в першій половині місяця в інтервалі низьких величин радіоактивного фону середовища. Побудовано просторово-часовий розподіл місцевої сейсмічності, горизонтальних рухів кори та радіоактивного фону в Закарпатському внутрішньому прогині за березень 2020 року (рисунок 10).

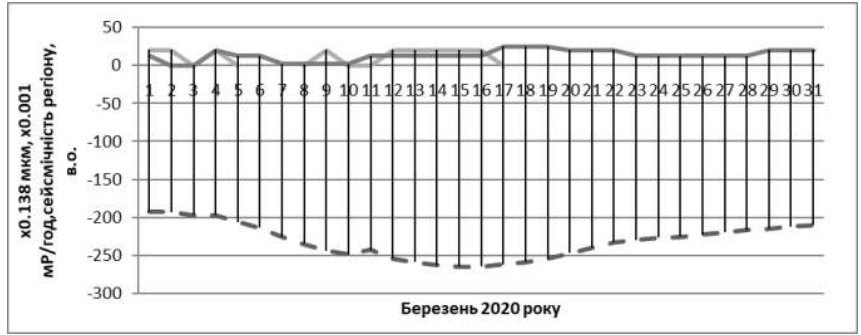

Рис. 10. Сейсмічність регіону (діаграма сірого кольору);

рухи кори (штрих-лінія); радіоактивний фон (діаграма чорного кольору). Березень 2020 року

Сейсмічність в березні 2020 року зростає в інтервали стиснення порід верхніх шарів земної кори, виміряних на пункті деформометричних спостережень „Королеве”. Радіоактивний фон 
зростає при динамічній зміні геомеханічних рухів. Квітень 2020 року характерний 17 місцевими землетрусами, радіоактивним фоном середньомісячна величина якого становить: 0.0147 мР/год (рисунок 11, а). Комплексний аналіз сейсмічного стану та радіоактивного фону в квітні 2020 року представлено на рисунку 12, б.

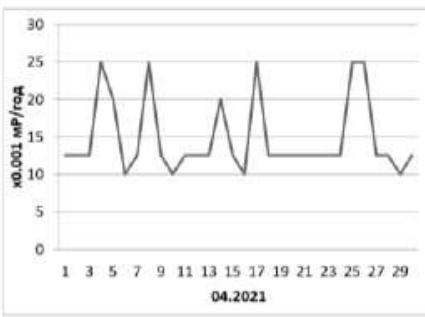

a)

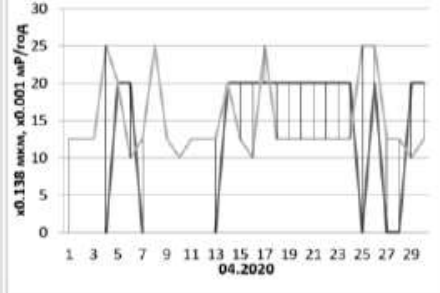

б)

Рис. 11. а) Радіоактивний фон середовища в квітні 2020 року. РГС «Тросник»; б) Радіоактивний фон (крива сірого кольору), сейсмічність регіону (крива чорного кольору). Квітень 2020 року. Закарпатський внутрішній прогин.

Сейсмічність відмічена в період між двома максимумами радіоактивного фону через добу. Розглянуто геофізичний стан регіону-побудувавши криву сучасних горизонтальних рухів кори за квітень 2020 року, величина розширення кори становить $+4.05 \times 10^{7}$ (рисунок 12).

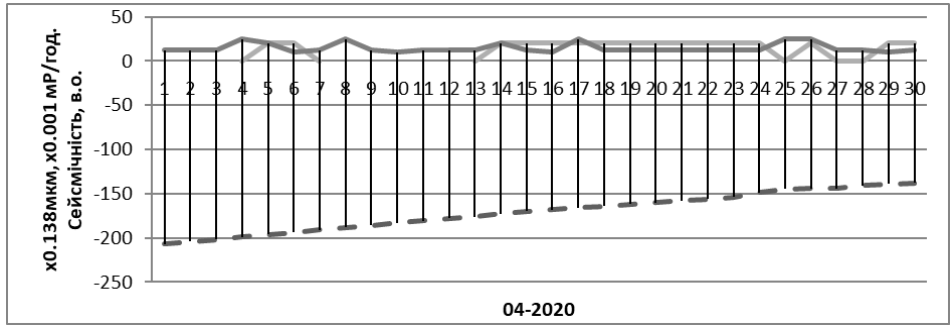

Рис. 12. Комплексний графік залежності геофізичних параметрів за квітень 2020 року: Сейсмічність регіону (крива сірого кольору), радіоактивний фон середовища (крива чорного кольору), рухи кори (штрих-лінія). Закарпатський внутрішній прогин 
Загальний характер рухів кори в квітні 2020 року-розширення кори. Представлено варіації параметрів сейсмічності, радіоактивного фону середовища та швидкості сучасних горизонтальних рухів кори (рисунок 13).

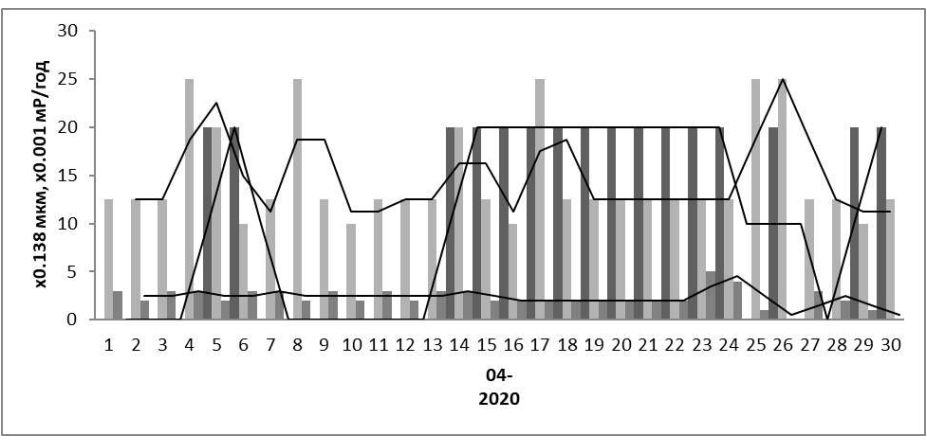

Рис. 13. Сейсмічність регіону (діаграма чорного кольору), швидкість рухів кори (діаграма сірого кольору), радіоактивний фон середовища (діаграма світло-сірого кольору). Квітень 2020 року, Закарпатський внутрішній прогин

Аналіз результатів геофізичних спостережень за квітень 2020 року відмітив особливості геодинаміки регіону: максимальна швидкість рухів кори супроводжується підвищенням величини радіоактивного фону середовища; швидкість рухів кори корелюється із активізацією сейсмічності-пониження швидкості руху відповідає інтервалам реєстрації місцевих землетрусів.

Розглянуто зв'язок радіоактивного фону середовища із динамікою рухів кори за травень 2020 року (рисунок 14).

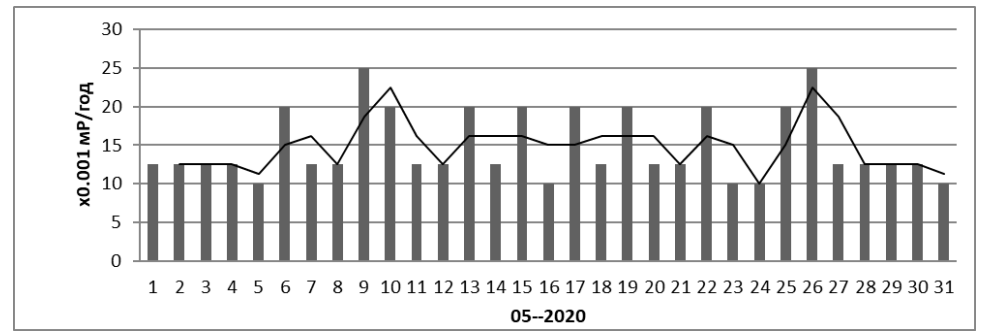

Рис. 14. Варіації радіоактивного фону середовища в травні 2020 року 
В травні 2020 року зареєстровано20 місцевих землетрусів на території Закарпатського внутрішнього прогину, середньомісячна величина радіоактивного фону становить $0.014 \mathrm{MP} / г о д$, сучасні рухи кори представляють стиснення порід величиною: -1.23 х10-7. Представлено просторово-часовий розподіл місцевої сейсмічності, кінематики рухів кори та варіацій бета випромінювання в центральній частині Закарпатського внутрішнього прогину (рисунки $15,16,17$ ).

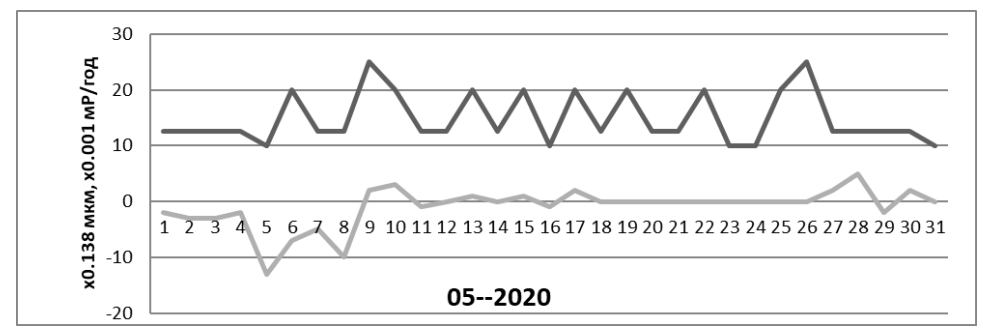

Рис. 15. Кінематика сучасних горизонтальних рухів кори (крива сірого кольору), варіації радіоактивного фону середовища (крива чорного кольору) в травні 2020 року. Закарпатський внутрішній прогин

Інтервали інтенсивних рухів кори в зоні Оашського розлому супроводжуються підвищеними величинами радіоактивного фону середовища. Розглянуто динаміку геофізичних полів за травень 2020 року (рисунок 16).

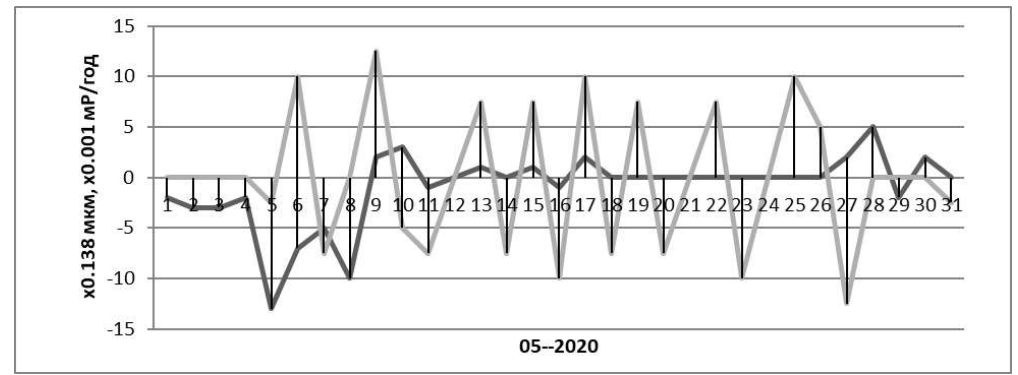

Рис. 16. Кінематика геофізичних полів в травні 2020 року. Закарпатський внутрішній прогин 
Сучасна траєкторія розвитку науково-технічного прогресу в Україні та світі

Зміни радіоактивного фону середовища викликані змінами динаміки рухів кори-стиснення порід супроводжується підвищенням величини радіоактивного фону середовища. Варіації радіоактивного фону середовища - в одних інтервалах часу із змінами швидкості руху кори: стиснення та розширення кори супроводжується інтенсивними бета випромінюваннями із періодами 2-3 доби.

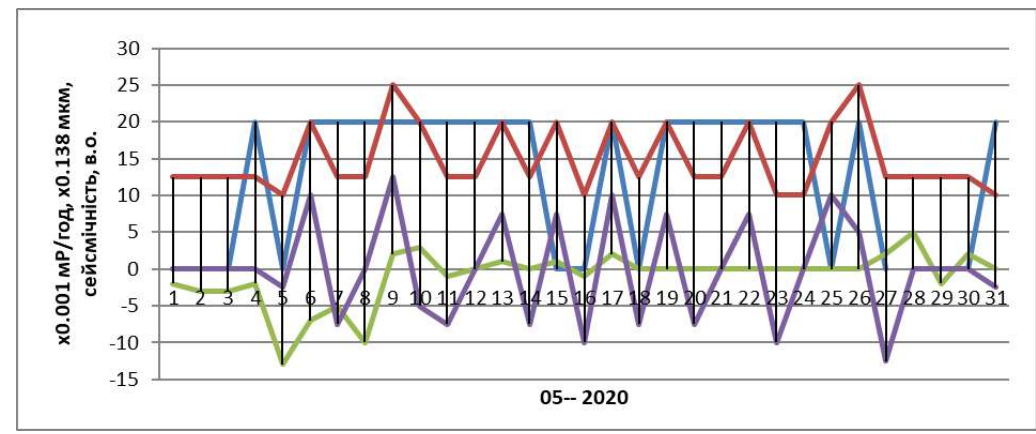

Рис. 17. Сейсмічність (крива синього кольору), швидкість рухів кори (крива зеленого кольору), кінематика рухів кори (крива фіолетового кольору), радіоактивний фон середовища (крива червоного кольору). Травень 2020 року. Закарпатський внутрішній прогин

Сейсмічність реєструється в інтервалах інтенсивних змін параметрів рухів кори та радіоактивного фону середовища.

Червень 2020 року. Червень 2020 року відмічений 25 місцевими землетрусами, які зареєстровані сейсмічними станціями та не $\epsilon$ відчутними. Проведені вимірювання радіоактивного фону на пункті спостереження (с. Тросник, Берегівський район) показали варіацію параметрів радіоактивності середовища, розраховано середньомісячну величину бета-випромінювання середовища, яке становить 0.01787 мР/год. Вимірювання сучасних горизонтальних рухів в зоні Оашського розлому проведені на пункті деформометричних спостережень „Королеве” відмітили стиснення величиною -10.53 x10-7. За результатами геофізичних спостережень в червні 2020 року побудовано графіки залежностей фізичних величин від 
часу: радіоактивного фону, сейсмічної активності, сучасних горизонтальних рухів кори та їх параметрів (рисунок 18).

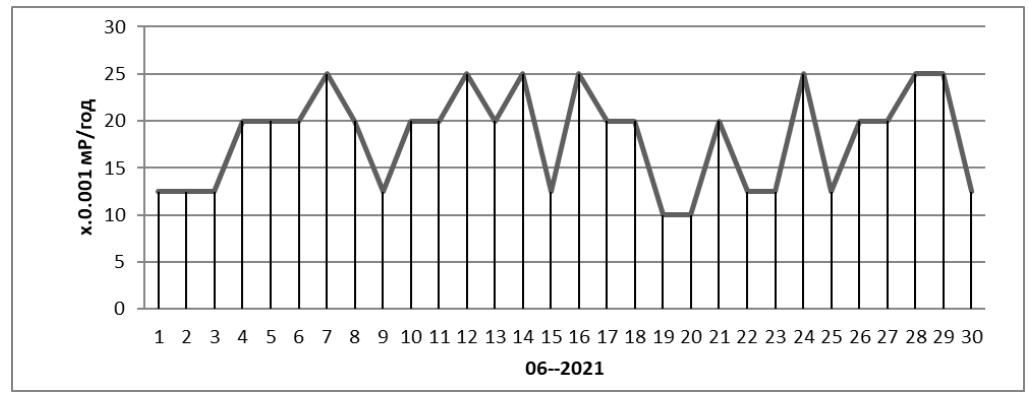

Рис. 18. Бета-випромінювання на РГС «Тросник» в червні 2020 року

Величина бета-випромінювання варіює в межах 10-25 мкР/год, періоди коливання знаходяться в діапазоні 2-5 діб. Розглянуто параметри сучасних горизонтальних рухів кори-зміщення порід на ПДС „Королеве” в комплексі із варіаціями фізичного поля (рисунок 19).

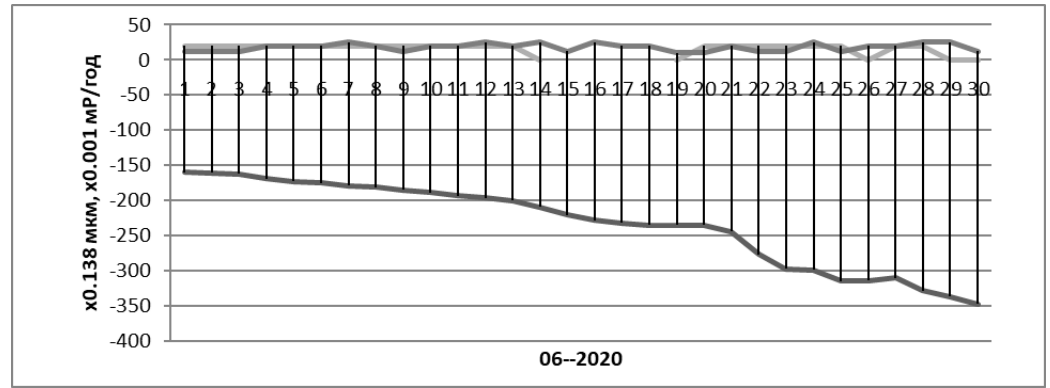

Рис. 19. Зміщення кори в зоні Оашського глибинного розлому (крива чорного кольору), варіації радіоактивного фону середовища (крива сірого кольору) в червні 2020 року. Закарпатський внутрішній прогин

Радіоактивний фон змінювався на фоні стиснення порід. Розширення порід супроводжується збільшенням величини бета- випромінювання. Розглянуто просторово-часовий розподіл 
Сучасна траєкторія розвитку науково-технічного прогресу в Україні та світі

місцевої сейсмічності в червні 2020 року на предмет дослідження впливу геофізичних полів на прояв місцевої сейсмічності (рисунок 20).

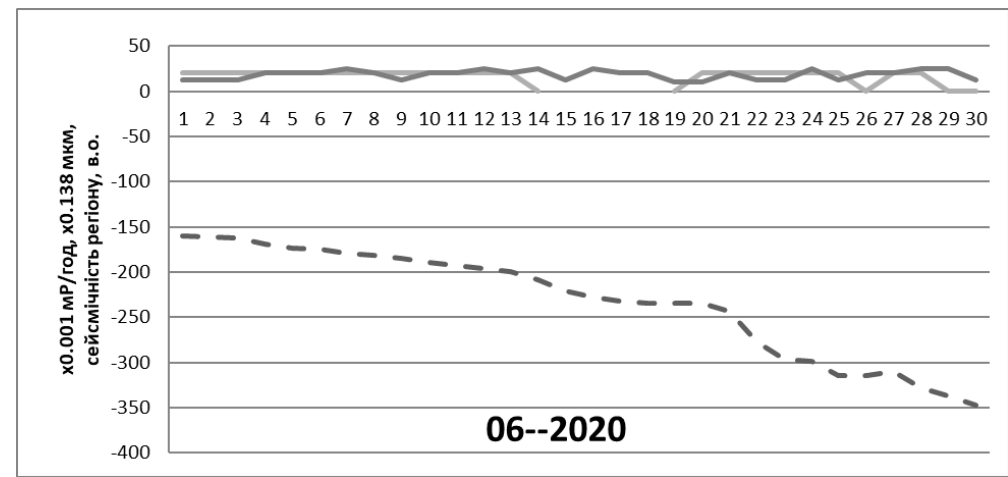

Рис. 20. Рухи кори (штрих-лінія), сейсмічність регіону (крива сірого кольору), радіоактивний фон (крива чорного кольору). Червень 2020 року. Закарпатський внутрішній прогин

Сейсмічна активізація регіону проходить в процесі стиснення порід в центральній частині Закарпатського внутрішнього прогину. Показано динаміку сучасних горизонтальних рухів в червні 2020 року та варіацію бета випромінювання в регіоні за досліджуваний період (рисунок 21).

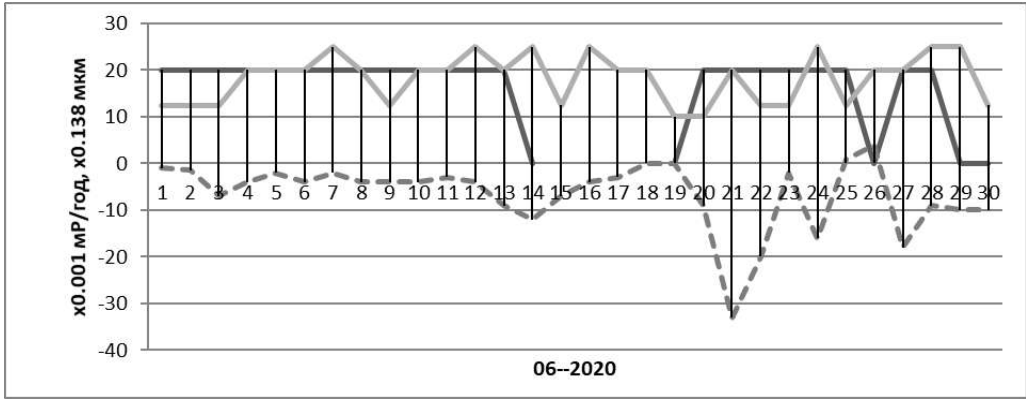

Рис. 21. Сейсмічність регіону (крива чорного кольору), варіації радіоактивного фону (крива сірого кольору), швидкість рухів земної кори (штрих-лінія). Червень 2020 року. Закарпатський внутрішній прогин 
Сучасна траєкторія розвитку науково-технічного прогресу в Україні та світі

Використання кінематики сучасних рухів кори дозволило отримати картину зв'язку рухів кори та геофізичного поля: підвищення величини радіоактивного фону середовища відмічено в періоди швидких сучасних рухів кори - стиснень порід (проходить вивільнення продуктів радіоактивного розпаду).

Липень 2020 року. В липні 2020 року сейсмічними станціями в регіоні зареєстровано 51 місцевий землетрус малої магнітуди. Результати спостережень бета -випромінювання на пункті спостереження представлено на рисунку 22. Розраховано середню величину бета-випромінювання за червень 2020 року, яка становить: 0.01616 мР/год.

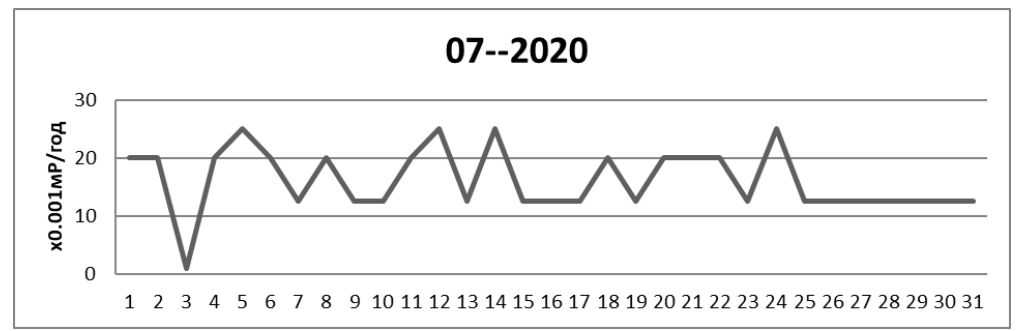

Рис. 22. Радіоактивний фон середовища в липні 2020 року. Закарпатський внутрішній прогин

Представлено рухи кори в липні 2020 року, проаналізовано інтервали часу із аномальними варіаціями геофізичних полів (рисунок 23).

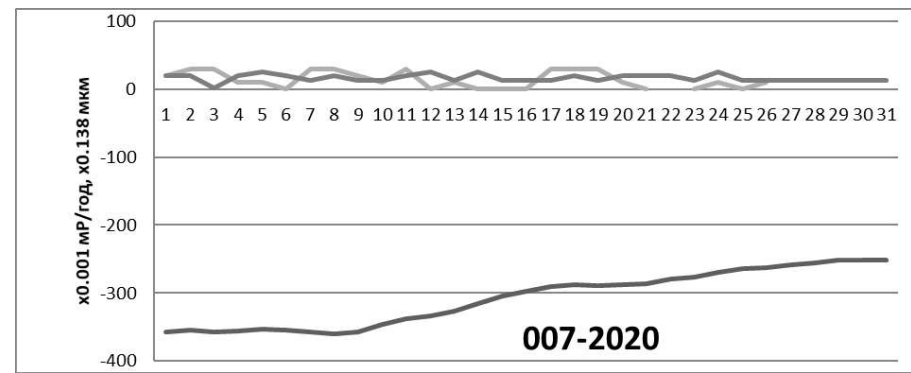

Рис. 23. Рухи кори (крива чорного кольору), радіоактивний фон середовища (крива сірого кольору) в липні 2020 року. Закарпатський внутрішній прогин 
Сучасна траєкторія розвитку науково-технічного прогресу в Україні та світі

Амплітуди коливань радіоактивного фону на початку місяця більші, в інтервалі нульових рухів кори, розширення кори супроводжується зменшенням амплітуди коливання параметрів радіоактивного фону середовища. Актуально розглянути просторово-часовий розподіл місцевої сейсмічності на фоні сучасних горизонтальних рухів кори та варіацій параметрів радіоактивного фону (рисунок 24).

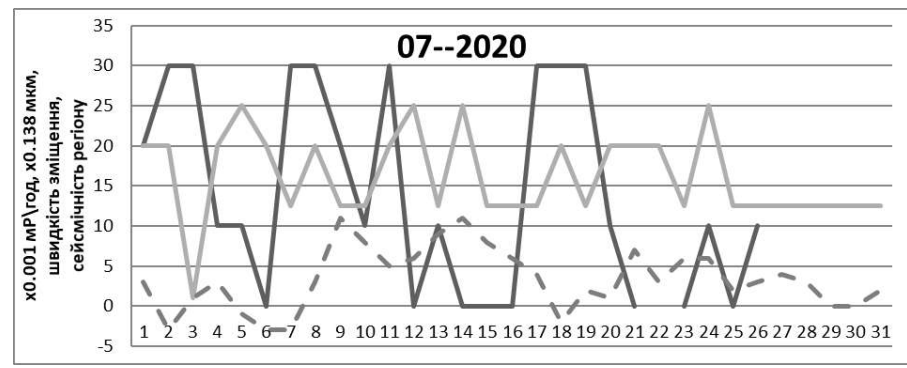

Рис. 24. Сейсмічність регіону (крива чорного кольору), радіоактивний фон середовища (крива сірого кольору), швидкість рухів кори (штрих лінія). Липень 2020 року. Закарпатський внутрішній прогин

Сейсмічність регіону представлена серіями місцевих слабих землетрусів в першій та другій декаді місяця. Радіоактивний фон середовища, його максимуми співпадають у часі із реєстрацією місцевих підземних поштовхів (рисунок 24). Динаміка горизонтальних рухів земної кори представлена варіацією швидкості зміщень земної кори: точки максимумів та мінімумів кривої швидкості рухів кори зсунуті на 1-2 доби, рухи кори в часовому аспекті передують варіаціям радіоактивного фону середовища. Таким чином, підтверджується припущення реакції геофізичних полів на зміну геодинамічного стану регіону: рухи кори викликають зміну фізичних характеристик гірських порід, що складають верхні шари земної кори, що відображається в варіаціях параметрів цих геофізичних полів.

\section{3. Аналіз геофізичних полів в річному діапазоні за 2020 рік. Радіоактивний фон середовища}

Середнє значення радіоактивного фону середовища за 2020 рік становить: 0.0158 мР/год (рисунок 25). 
Сучасна траєкторія розвитку науково-технічного прогресу в Україні та світі

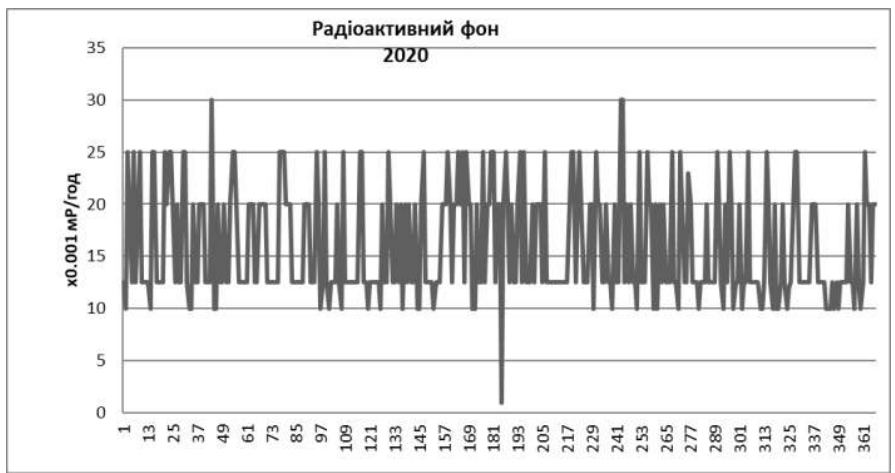

Рис. 25. Радіоактивний фон середовища на РГС «Тросник» за 2020 рік

Зміщення порід в зоні Оашського глибинного розлому за 2020 рік становить: $-2.53 \times 10^{-7}$ (стиснення) (рисунок 26).

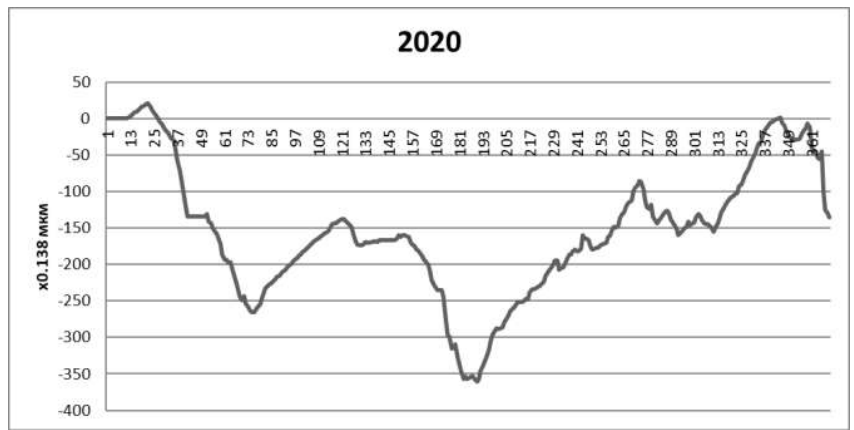

Рис. 26. Зміщення порід в зоні Оашського глибинного розлому за 2020 рік

Сейсмічність регіону представлена просторово-часовим розподілом (рисунок 28). 
Сучасна траєкторія розвитку науково-технічного прогресу в Україні та світі

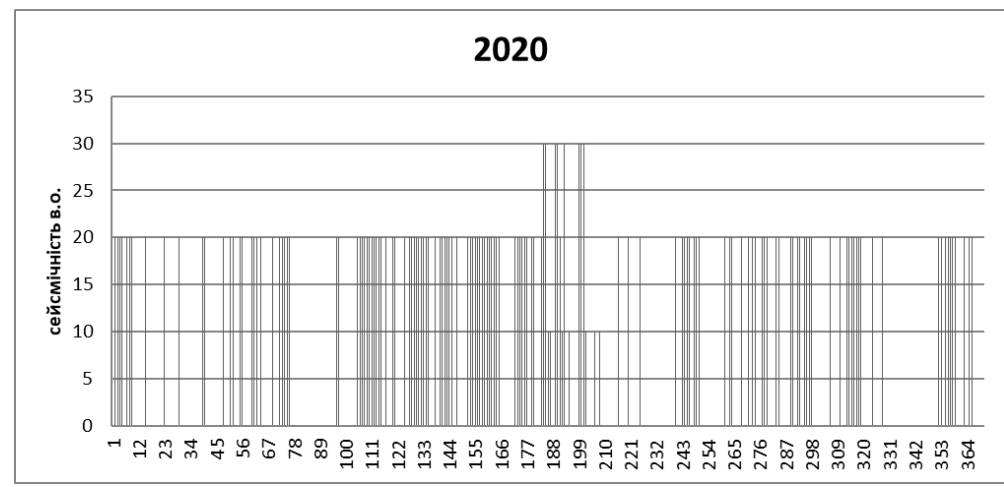

Рис. 27. Просторово-часовий розподіл місцевої сейсмічності в Закарпатському внутрішньому прогині за 2020 рік

За 2020 рік на території Закарпатського внутрішнього прогину відбулося 188 місцевих землетрусів. Швидкість рухів кори в зоні Оашського глибинного розлому за 2020 рік представлено на рисунку 29.

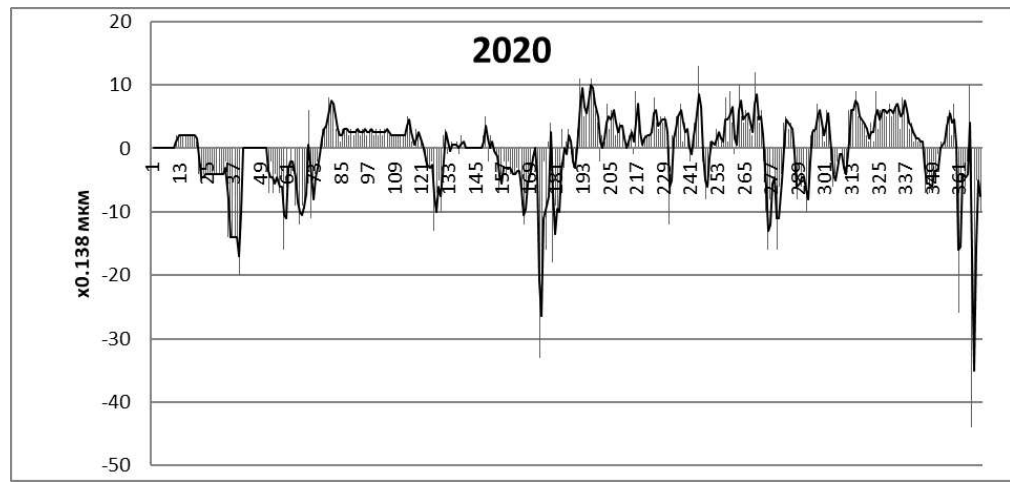

Рис. 28. Швидкість рухів кори в зоні

Оашського глибинного розлому за 2020 рік

Проаналізовано зв'язок параметрів геофізичних полів із місцевою сейсмічністю в річному діапазоні (рисунок 30 ). 


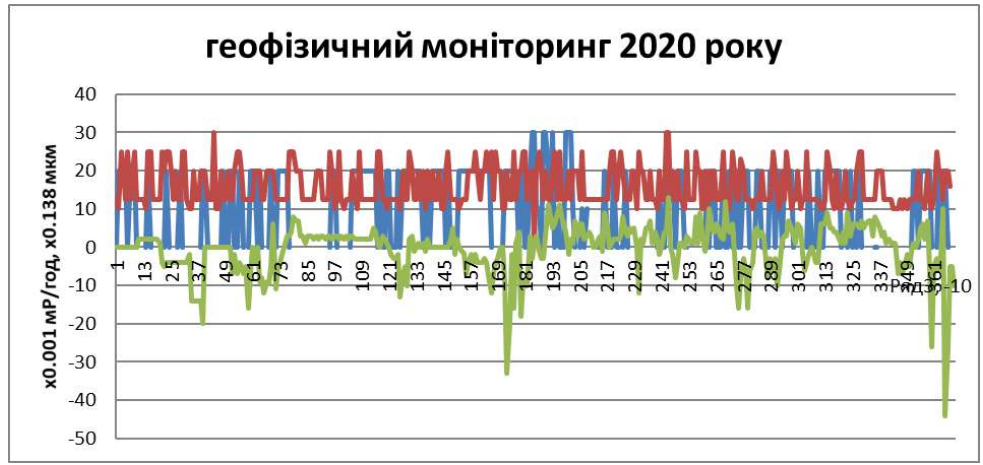

Рис. 29. Радіоактивний фон середовища (діаграма червоного кольору), сейсмічність регіону (діаграма синього кольору), швидкість зміщення верхніх шарів земної кори (діаграма зеленого кольору). 2020 року. Закарпаття

Найбільш активні в сейсмічному прояві інтервали часу пов'язані із аномальними рухами кори, в цей же період радіоактивний фон середовища також характерний динамічними змінами параметрів. Сучасні горизонтальні рухи кори, динаміка їх зміни супроводжуються активізацією місцевої сейсмічності та зростанням радіоактивного фону середовища.

\section{Висновки}

Проведені геофізичні спостереження в Закарпатському внутрішньому прогині в 2020 році підтвердили отримані висновки попередніх періодів досліджень геодинамічного стану регіону.

За 2020 рік на території Закарпатського внутрішнього прогину сейсмічними станціями Відділу сейсмічності Карпатського регіону Інституту геофізики ім. С.І. Субботіна НАН України зареєстровано 188 місцевих землетрусів. 23 січня 2020 року зареєстровано відчутний місцевий землетрус інтенсивністю 4 бали за шкалою MSK-64, епіцентр якого знаходився на території Берегівського району Закарпатської області.

Геодинамічний стан регіону визначався за результатами деформометричних спостережень в зоні Оашського глибинного розлому на пункті деформометричних спостережень „Королеве”. Загальний характер сучасних горизонтальних рухів кори за весь 
Сучасна траєкторія розвитку науково-технічного прогресу в Україні та світі

період спостережень становить: $+10 \times 10^{-7}$. За 2020 рік спостерігали стиснення порід величиною: $-2.57 \times 10^{-7}$.

Починаючи з 2012 року, горизонтальні рухи характерні знакозмінними процесами, до цього періоду спостерігали розширення порід. Підтверджується гідрологічний аспект місцевої сейсмічності. Геофізичні поля реагують на сейсмотектонічні процеси в регіоні.

Параметри радіоактивного фону (бета випромінювання) спостережувані на РГС „Тросник” корелювали із сучасними горизонтальними рухами кори в зоні Оашського глибинного розлому: стиснення порід супроводжувалися підвищеним радіоактивним фоном. Сейсмічність регіону супроводжує інтенсивні рухи кори, згідно часового розподілу швидкостей сучасних горизонтальних рухів кори. Актуальність проведених досліджень викликана періодичністю сейсмотектонічних процесів та зменшення частоти прояву відчутних місцевих землетрусів. Для даного регіону частота прояву відчутних місцевих землетрусів становить від 2-х до 6 підземних поштовхів. Тому важливо продовження вивчення зв'язку геофізичних полів із сейсмотектонічними процесами та вирішення проблем екологічного стану регіону.

\section{Література:}

1. М. Орлюк, А. Марченко, М. Бакаржієва. 3D Магнітна модель земної кори Східноєврропейського кратону 3 урахуванням сферичності Землі та її тектонічна інтерпретація. Вісник Київського національного університету імені Тараса Шевченка. Геологія 4(79)/2017.cc-21-26. ISSN 1728-2713.

2. Г. Кулієв. Про особливості розповсюдженнч пружних хвиль візотропних середовищах за високих і надвисоких тисків. Вісник Київського національного університету імені Тараса Шевченка. Геологія 4(79)/2017. сc.27-34. ISSN 1728-2713.

3. О. Кендзера, Ю. Семенова. Деформаційні характеристики розрахункових моделей грунтової товщі. Вісник київського національного університету імені Тараса Шевченка. Геологія 3(78)/2017.

4. Д. Малицький, А. Муровська, ,О. Обідіна, А. Гнип, О. Грицай, А. Павлова, А. Пугач. Визначення полів напружень у земній корі за механізмами вогнищ землетрусів у Закарпатті. Вісник Київського національного університету імені Тараса Шевченка. Геологія 3(78)/2017. C. 36-45. ISSN 1728-2713. 
Сучасна траєкторія розвитку науково-технічного прогресу в Україні та світі

5. К. Нікітченко. Сучасні підходи до виділення та моделювання магнітного поля літосфери. Вісник Київського національного університету імені Тараса Шевченка. Геологія 3(78)/2017. С. 51-59.

6. Д. Малицький, А. Муровська, О. Гінтов, А. Гнип, О. Обідіна, С. Мичак, О.Грицай, А. Павлова. Механізми вогнищ землетрусів та поле напружень Солотвинської западини Закарпаття. Вісник Київського національного університету імені Тараса Шевченка. Геологія 2(77)/2017.cc.43-51. ISSN 1728-2713.

7. 3. Вижва, В. Демидов, А. Вижва. Статистичне моделювання двовимірного випадкового поля з кореляційною функцією типу Коші в геофізичній задачі моніторингу довкілля. Вісник Київського національного університету імені Тараса Шевченка. Геологія 1(76)/2017. С. 93-99. ISSN 1728-2713

8. С. Вижва, Г. Лісний, В. Круглик. Застосування графічних процесорів для побудови сейсмічних зображень геологічного середовища. Вісник Київського національного університету імені Тараса Шевченка. Геологія 4(75)/2016. С. 45-49.

9. М. Орлюк, А. Марченко, А. Роменець. Зв'язок сейсмічності Землі та вікових змін їі магнітного поля. Вісник Київського національного університету імені Тараса Шевченка. Геологія 4(75)/2016. С. 5-054. ISSN 1728-2713.

10. В. Зацерковний, І. Тішаєв, Р. Шульга. Джерела походження та взаємодія мікросейсми з геологічним середовищем. Вісник Київського національного університету імені Тараса Шевченка. Геологія 4(75)/2016. С. 82-87. ISSN 1728-2713.

11. 0. М. Гнилко. Структури латерального витискання в Карпатах. Геодинаміка 1(22)/2017. С. 16-25. ISSN: 1992-142X (Print) 2519-2663 (Online).

12. Е. Д. Кузьменко, С. М. Багрій, I. В. Чепурний, М. В. Штогрин. Оцінка небезпеки при поверхневих деформацій гірських порід у межах Стебницького калійного родовища методом ПІЕМПЗ. Геодинаміка 1(22)/2017. C. 98-113.

13. S. SAVCHUK, S. DOSKICH. MONITORING OF CRUSTAL MOVEMENTS IN UKRAINE USIN. Геодинаміка 2(23)/2017. C. 7-13.

14. О. Тадеєв. До проблеми елімінації ефектів втрати інваріантності в оцінюванні деформаційних полів Землі за GNSS-даними. Геодинаміка 2(23)/2017. С. 34-45. https://doi.org/10.23939/jgd2017.02.034.

15. Л. Мончак, С. Анікеєв. Відображення тектонічної будови західного регіону України у гравімагнітних полях. Геодинаміка 2(23)/2017. С. 104-118. 
Сучасна траєкторія розвитку науково-технічного прогресу в Україні та світі

16. В. Коболев. Земля: Виртуальность тектоніки плит, конформность фиксизма и мобилизма. Геодинаміка 2(23) 2017. C. $119-140$.

17.0. Ступка. “Молоді платформи” - Традиційні уявлення i реальність (геодинамічний аспект). Геодинаміка 1(24) 2018. C. 51-59.

18. М. Орлюк , А. Марченко , П. Яцевський. Зв'язок радонових і магнітних аномалій на території Українського щита та міста Києва. Геодинаміка 1(24) 2018. С. 80-90.

19 Д. Малицький, А. Гнип, О. Грицай, А. Муровська, С. Кравець, Е. Козловський, А. Микита. Механізм вогнища і тектонічний контекст землетрусу 29.09.2017 p. Поблизу м. Стебник. Геодинаміка 1(24) 2018. С. 100-110.

20. О. Кендзера, Ю. Семенова. Вплив осадової товщі на сейсмічні коливання на території Ташлицької гідроакумулювальної електростанції. Геодинаміка 1(24) 2018. С. 91-99.

21. Ігнатишин В.В., Іжак Т.Й., Ігнатишин М.Б., Ігнатишин А.В. Зв'язок геофізичних полів із геодинамічним станом в Закарпатському внутрішньому прогині. Матеріали Всеукраїнської науково-практичної інтернет конференції „Вітчизняна наука на зламі епох : проблеми та перспективи розвитку,, : Зб. Наук. Праць. - Переяслав-Хмельницький, 2019. -Вип. 48. - 227 с. С. 9-15.

22. Ігнатишин В.В., Іжак Т.Й., Ігнатишин М.Б., Ігнатишин А.В. Зв'язок гідрогеологічного та сейсмотектонічного станів в Закарпатському внутрішньому прогині. Збірник наукових матеріалів XXУII Міжнародної науково- практичної інтернет конференції „Інноваційні пріоритети у розвитку науки,, 18 Лютого 2019 року. Частина 1. м. Вінниця. С. 61-67. 76 с. (6 ст.).

23. В.В. Ігнатишин, Т.Й. Іжак, М.Б. Ігнатишин, А.В. Ігнатишин. Дослідження геофізичних процесів в Закарпатському внутрішньому прогині „Географія та туризм: Матеріали II Всеукраїнської науковопрактичної конференції Харківського національного педагогічного університету ім. С.I. Сковороди (26 лютого 2019 року) м. Харків) / за заг.редакцією проф. Стадника О.Г.-Харків : ХНПУ ім. Г.С. Сковороди, 2019-252 c. (39-47c).

24. Ігнатишин В.В., Ігнатишин М.Б., Ігнатишин А.В. Дослідження геодинамічних процесів в Закарпатському внутрішньому прогині. Збірник тез наукової конференції „Здобутки і перспективи розвитку геологічної науки в Україні,, присвячену 50-річчю Інституту геології, геохімії та рудоутворення імені М.П. Семененка, (Київ, 14-16 травня 
Сучасна траєкторія розвитку науково-технічного прогресу в Україні та світі

2019 року). У 2-х томах / НАН України, IH-т геохімії, мінералогії та рудоутворення ім. М.П. Семененка. - Київ, 2019. - Т. 1. - 244 с. C. 19-20. ISDN 978-966 02-8897 3.

25. Ігнатишин В.В. Застосування результатів геофізичних спостережень при вивченні геодинамічного стану Закарпатського внутрішнього прогину. Матеріали XXIУ Міжнародної науковометодичної конференції ,Управління якістю підготовки фахівців,,, 18-19 квітня 2019 року. м. Одеса. Частина 2.204 с. С. 55-58. ISSN 2412-1932.

26. Ігнатишин В.В., Іжак Т.Й., Ігнатишин А.В., Ігнатишин М.Б. Зв'язок деформацій земної кори із сейсмічністю Закарпатського внутрішнього прогину за 2017 рік. Регіон - 2019: суспільногеографічні аспекти: матеріали міжнародної науково практичної конференції студентів, аспірантів та молодих науковців (м. Харків, 11 - 12 квітня 2019 р.) / Гол. ред. колегії Л.М. Нємець. - Х.: ХНУ імені В.Н. Каразіна, 2019. - 165 С. 146-149.

27. Ігнатишин В.В., Іжак Т.Й., Ігнатишин М.Б., Ігнатишин А.В. Кінематика сучасних горизонтальних рухів земної кори та сейсмічний стан Закарпатського внутрішнього прогину за 2017 рік. Материалы Международной научно-практической интернет-конференции «Тенденции и перспективы развития науки и образования в условиях глобализации»: Сб. науч. трудов. - Переяслав-Хмельницкий, 2019. - Вып. 45. - 555 с. (c. 5-8).

28. В.В. Ігнатишин,Т.Й. Іжак, М.Б. Ігнатишин, А.В. Ігнатишин. Особливості сучасних горизонтальних рухів в зоні Оашського глибинного розлому та сейсмічна активність. Матеріали XIV Міжнародної науково-практичної інтернет-конференції «Проблеми та перспективи розвитку сучасної науки в країнах Європи та Азії» // Збірник наукових праць. - ПереяславХмельницький, 2019 р. - 163 с. (с. 23-26).

29. Ігнатишин В.В., Ігнатишин М.Б., Ігнатишин А.В. Особливості просторово-часового розподілу сейсмічності Закарпатського внутрішнього прогину та геодинамічний стан регіону. Матеріали дев'ятої міжнародної науково-практичної конференції „Комплексне забезпечення якості технологічних процесів та систем,.. 14-16 травня 2019 року. М. Чернігів. Том 2. С. 185-187.

30. URL: https://www.google.com/maps/d/pdf?mid=1a8Caxd_IRw0 Gn840Tr41rfgQVGLMvUp\&hl=ru\&pagew=792\&pageh=612\&llsw=47.391 $482 \% 2$ C21.802482\&llne $=49$. 